\title{
ANALISIS CITY BRANDING DALAM PENGEMBANGAN DESTINASI PARIWISATA KABUPATEN JAYAPURA
}

\author{
Ari Bawanti \\ Alumni Sekolah Tinggi Pariwisata AMPTA Yogyakarta \\ ariewibawanti@gmail.com>
}

\begin{abstract}
Jayapura district is a district located in the province of Papua. Unidirectional on the vision and mission of "New Jayapura district" makes the Jayapura district currently holds the role as the major developments in the polar region in particular of Jayapura. But the Jayapura district has not had the appropriate brand status in the field of tourism. In the framework of marketing and competition in the world of tourism, of course not wrong if Jayapura district also boasts a unique identity that expresses the uniqueness of Jayapura district itself.

This study aims to determine views or perceptions of market participants travel (tourists) on the formation of a destination image Jayapura district and identify the elements of the establishment of a brand that is suitable for city branding prepare for Jayapura district. The method used is the method mix between quantitative and qualitative methods by taking a sample of 30 respondents rating, which then disedkripsikan perception of market participants travel to the image of Jayapura District as a destination and the elements of what is appropriate to draw up branding Jayapura city. The results showed that the image of Jayapura district as a tourism destiinasi is unique, comfortable, Lake Sentani, culture, youth and diversity of nature.
\end{abstract}

Keywords: City branding, Jayapura district, the image of the destination.

\section{PENDAHULUAN}

Pariwisata adalah suatu perjalanan yang dilakukan untuk rekreasi atau liburan dan juga persiapan yang dilakukan sebagai aktivitas. Pilihan tujuan berwisata merupakan indikator gaya hidup bagi konsumen yang memilih untuk menghabiskan waktu santai mereka dengan berlibur. Seperti yang kita ketahui saat ini perjalanan untuk berwisata semakin menyerap wacana kehidupan sehari-hari baik dari kalangan muda hingga orang tua. Pariwisata seringkali dipersepsikan sebagai mesin ekonomi peng- hasil devisa bagi pembangunan ekonomi di suatu destinasi. Namun demikian, pada prinsipnya pariwisata memiliki spectrum fundamental pembangunan yang lebih luas bagi suatu negara. Sektor pariwisata telah diakui sebagai cara yang paling efektif bagi negara berkembang untuk meningkatkan penerimaan devisa, yaitu untuk mendorong pembangunan dalam rangka percepatan pertumbuhan regional. Keinginan untuk mendapatkan pendapatan yang tinggi menjadikan pengelola setiap kota atau destinasi sangat terbuka terhadap modal pembangunan destinasi khususnya dalam 
pengembangan pariwisata. Dalam hal ini perlu adanya suatu konsep manajemen perkotaan yang baik. Salah satunya adalah dengan pembentukan konsep suatu citra atau image yang dapat menonjolkan identitas destinasi demi memasarkan destinasi tersebut.

Citra atau image merupakan unsur penting bagi sebuah destinasi pariwisata. Hal ini disebabkan oleh karena citra merupakan cerminan atau gambaran kondisi dari unsur-unsur yang dimiliki dalam destinasi tersebut pada kurun waktu yang relatif cukup lama. Oleh karena itu wisatawan akan menggunakan citra destinasi wisata sebagai panduan yang akan mewakili dalam proses pengambilan keputusan, apakah akan berkunjung kesuatu destinasi atau tidak. Citra destinasi merupakan sekumpulan informasi mengenai unsur-unsur pembentuk destinasi tersebut sehingga citra destinasi akan mempengaruhi persepsi wisatawan terhadap unsur-unsur produk yang ditawarkan oleh destinasi tersebut. Sehingga dapat dikatakan apabila citra suatu destinasi tersebut jelas, maka calon wisatawan mempunyai gambaran yang cukup jelas mengenai produk wisata yang ada di destinasi tersebut. Suatu destinasi penting memiliki citra yang kuat dan positif karena citra tersebut mempunyai pengaruh langsung terhadap penentuan untuk dikunjungi atau tidak. Hal ini disebabkan karena wisatawan biasanya memilih suatu destinasi berdasarkan image destinasi tersebut atau persepsinya terhadap image tersebut.

Beberapa destinasi di Indonesia sudah mulai menggunakan brand tertentu untuk memasarkan daya tarik destinasi pariwisatanya. Seperti Jakarta dengan "Enjoy Jakarta", berusaha mengajak para wisatawan untuk menikmati ibukota Negara dengan berbagai kemudahan yang ditawar- kan. Dekat dengan pusat pemerintahan, pusat perbelanjaan modern sampai dengan hiburan malam. Begitu juga dengan Jogjakarta yang memiliki brand "Jogja Istimewa" mengajak wisatawan merasakan keistimewaan Jogja yang progresif, integritas dan dianggap memiliki diferensi yang kuat dibanding daerah lainnya.

Kabupaten Jayapura merupakan kabupaten yang terletak di Provinsi Papua. Searah pada visi dan misinya yaitu "Kabupaten Jayapura Baru" menjadikan Kabupaten Jayapura saat ini memegang peranan sebagai kutub perkembangan utama di Papua khususnya kawasan Jayapura. Kabupaten Jayapura sendiri memiliki potensi yang besar yang dapat dikembangkan misalnya sumber daya alam yang ada dan budaya masyarakat sekitar.

Posisi sektor pariwisata Kabupaten Jayapura sangat penting sebagai salah satu bisnis inti Kabupaten Jayapura. Dengan penetapan pariwisata sebagai salah satu bisnis inti, perhatian pemerintah terhadap pengembangan pariwisata akan bertambah besar dan pembangunan pariwisata menjadi prioritas dalam pembangunan daerah (Dinas Kebudayaan dan Pariwisata Kabupaten Jayapura, 2015).

Kabupaten Jayapura memiliki beberapa tempat wisata unggulan, seperti Danau Sentani yang merupakan danau terluas di Papua. Danau sentani memiliki luas kurang lebih 9000 hektar dan memiliki pulau-pulau kecil yang tersebar di danau ini. Ada sekitar 24 kampung yang menepati Danau Sentani, masing-masing kampung begitu unik dan memiliki tradisi masing-masing. Walaupun beragam ada yang menyatukan kampungkampung ini yaitu legenda. Begitu juga dengan wisata Pantai Harlem di Demta dan Situs Megalitic Tutari yang merupakan situs purbakala di Sentani Barat menjadi salah satu destinasi kunjungan yang popular 
di Kabupaten Jayapura. Ada juga beberapa objek lainnya yang menjadi tempat kunjungan wisatawan seperti Tugu Jendral Douglas Mac Artur di Ifar Gunung, situs Megalitikum di Doyo, Kampung Wisata Asei Pulau, Kampung Wisata Abar, Kampung Wisata Tablanusu dan wisatawisata lainnya.

Namun dalam hal ini Kabupaten Jayapura belum memiliki status brand yang sesuai dibidang kepariwisataan. Dalam rangka marketing dan persaingan dalam dunia pariwisata, tentu saja tak salah seandainya Kabupaten Jayapura juga menonjolkan suatu identitas unik yang mengekpresikan keunikan Kabupaten Jayapura sendiri. Identitas inilah yang perlu digali dan ditonjolkan sebagai usaha peningkatan kolektif bagi warga di Kabupaten Jayapura.

Dari latar belakang yang telah dipaparkan diatas, penulis tertarik untuk melakukan sebuah reaserch atau penelitian dengan judul "Analisis City Branding Dalam Pengembangan Destinasi Pariwiisata Kabupaten Jayapura". Penelitian ini dilakukan guna mencari tau bagaimana persepsi atau cara pandang pihak pemerintah, masyarakat dan wisatawan tentang adanya sebuah brand destinasi yang digunakan sebagai masukan kepada pihak pemerintah dalam kebijakan membuat city branding sebagai salah satu cara dalam pengembangan destinasi wisata di Kabupaten Jayapura.

Berdasarkan gambaran latar belakang diatas dapat disimpulkan bahwa keberadaan citra suatu destinasi melalui city branding adalah penting, karena citra tersebut akan mempengaruhi persepsi wisatawan dalam motivasi untuk datang berkunjung ke destinasi tersebut. Namun saat ini Kabupaten Jayapura belum memiliki city branding yang sesuai di bidang kepariwi- sataan. Masalah utamanya adalah (1) bagaimanakah persepsi pihak pemerin-tah dan pelaku pasar wisata (wisatawan) atau masyarakat terhadap sebuah brand destinasi? (2) apa saja unsur-unsur pembentukan city branding yang sesuai bagi Kabupaten Jayapura?. Oleh karena itu (1) perlu mengidentifikasi persepsi pihak pemerintah, pelaku pasar wisata dan masyarakat terhadap sebuah citra dalam pengembangan destinasi wisata, dan (2) menentukan unsur-unsur pembentukan city branding yang sesuai bagi Kabupaten Jayapura.

\section{LITERATUR REVIEW}

\section{Branding}

Menurut Kotler (2006:3) Branding itu tentang membawa sesuatu yang biasa dan meningkatkannya dengan cara-cara yang membuatnya menjadi lebih berharga dan bernilai. Ketika berbicara tentang brand sebagian orang akan segera ingat pada coca cola, aple, nokia, rinso dan mungkin aqua. Beberapa brand ini juga sering di kutip dalam bidang bisnis ke consumer. Bagi sebuah perusahaan brand mewakili aset yang kuat dan bertahan lama, pemicu nilai sebenarnya yang telah menaikkan kesuksesan perusahaan.

"Brand melayani tujuan umum yang persis sama dalam pasar seperti halnya pada consumer. Brand merupakan alat efektif untuk mengomunikasikan manfaat dan nilai suatu produk atau jasa. Brand merupakan jaminan kualitas, asal usul dan performa yang dengan demikian meningkatkan nilai yang dirasakan customer dan mengurangi resiko dalam keputusan membeli. Brand bersifat emosional, memiliki kepribadian, serta mencakup hati dan benak customernya" (Kotler, 2006:4) 
Brand sepenuhnya adalah persepsi segala sesuatu yang dilihat, dengar, baca, ketahui, dan rasakan pikirkan tentang suatu produk, jasa atau bisnis. Brand memiliki posisi istimewa di benak customer dalam menyederhanakan proses pengambilan keputusan.

Definisi, manfaat dan fungsi brand berlaku dalam sebuah bisnis pemasaran baik produk maupun perusahaan, Kotler (2006:8). Hal ini guna menciptakan dan mempertahankan keunggulan kompetitif yang berkesinambungan karena adanya brand.

"Whereas identity-based city branding focus on internal groups of a city (local residents, politicians or entrepreneurs), brand-image analysis explores how external groups perceive the city (tourists, potential investors or residents)" (Burman and Maffert in Caline Brandt 2011:2)

Hal ini mungkin akan menimbulkan pertanyaan "apa artinya ini bagi pelaksanaan city branding?". Faktor pertama yang menyangkut penafsiran city branding yaitu ada pandangan mayoritas pada inteprestasi city branding yang dapat merangsang pendekatan lebih koheren dan terpadu untuk sebuah branding terhadap pengmabilan keputusan.

"It is important to note that city branding Is part of the wider. Many observers have pointed out that place marketing and place branding could involve different types and different spetial scales" (Erick Braun, 2012:2)

Dalam parakteknya, brand destinasi dapat diterapkan untuk lingkungan, kabupaten, tujuan wisata, kota, pedesaan, daerah, negara bagian dan negara. Sebuah kota-kota di Indonesia saat ini, pemerintah juga menggunakan sebuah brand demi memperkenalkan keunikan kota sebagai bentuk pemasaran destinasi. Menciptakan sebuah brand berupa nama, symbol, logo dan grafis lainnya yang bisa mengilustrasikan tujuan dari kota tersebut. Brand ini akan memberikan tawaran kepada publik.

Ada beberapa hal yang dilakukan untuk membuat brand sebuah kota. Pertama, dalam menciptakan brand sebuah kota tidak harus terfokus pada pemasaran kota semata. Langkah-langkah yang dilakukan harus koheren dengan rencana pemasaran yang menyeluruh dan dimuat dalam strategi dari kota secara keseluruhan. Hal ini dimulai dengan melakukan riset dahulu terhadap potensi kota. Kemudian baru ditentukan visi apa yang ingin dicapai. Tahap selanjutnya adalah identitas apa yang harus ditentukan. Hal ini harus memperhitungkan sejarah dan persepsi publik baik itu internal maupun eksternal (warga, pengunjung, investor, media massa, lembaga-lembaga publik dan lai-lain). Yang terakhir adalah brand sebuah kota harus disebarkan dengan rencana komunikasi yang baik. Semua elemen publik menjalankan proses komunikasi ini, serta harus korehen agar tidak menimbulkan pembiasan persepsi brand kota oleh konsumen.

Brand sebuah kota tidak hanya harus sesuai dengan konsep pemasaran, namun juga harus mempunyai karakteristik :

1. Brand sebuah kota harus terdiri dari tiga elemen dasar : brand grafis, penciptaan symbol dan logo. Hal tersebut karena fungsi brand secara fungsional adalah berdasarkan poinpoin yang kuat dan menarik yang dimiliki oleh sebuah kota. Sedangkan fungsi brand secara emosional adalah simbolis dan personalisasi dari nilainilai yang terkait dengan kota.

2. Suatu brand dari suatu kota harus diciptakan dengan strategi tunggal 
yang berlaku untuk berbagai sektor publik.

3. Brand kota harus diciptakan untuk bertahan lama. Pemerintah kota atau daerah sekarang sudah mulai dengan otonomi dan bisa mengembangkan dengan baik.

\section{Citra Destinasi}

"Citra destinasi adalah kumpulan dari sejumlah keyakinan, ide dan kesan bahwa orang merasa memiliki destinasi tersebut. Sebagian orang menyatakan citra adalah kesan atau pengaruh dari apa yang dilihatnya. Namun, secara umum citra dapat diterjemahkan sebagai suatu pemahaman pribadi, internal, dan konseptual tentang apa yang diketahui" (Ali Hasan, 2015:139)

Daerah tujuan wisata adalah salah satu produk yang paling kompleks serta terbentuk dari berbagai faktor seperti iklim, infrastruktur dan berbagai atribut alam maupun budaya. Dalam hal ini suatu daerah tujuan wisata sangat memerlukan citra untuk dapat dijual sebagai produk pariwisata.

Berbagai riset menyatakan bahwa terdapat hubungan yang sangat erat antara citra suatu daerah tujuan wisata dengan kunjungan wisatawan. Untuk menciptakan suatu citra yang dapat memberikan pengaruh besar pada tingkat kunjungan wisatawan perlu terlebih dahulu dipahami bagaimna citra tersebut dibentuk. Salah satu pengaruh besar dalam pembentukan citra adalah pengalaman (experience) langsung yang dialami oleh wisatawan sebagai seorang konsumen. Dengan melakukan kontak langsung dengan daerah tujuan yang dikunjungi, maka akan terbentuk pikiran dan pemahaman serta kepercayaan seorang wisatawan terhadap daerah tujuan wisata tersebut.
Sementara proses untuk pembentukan citra itu sendiri sangat dipengaruhi oleh banyak faktor, baik dari lingkungan wisatawan sendiri maupun pengaruh yang diberikan oleh penyedia produk atau jasa pariwisata.

\section{Pengembangan Destinasi}

Menurut Carter dan Febricius dalam Bambang (2013:172) terdapat berbagai elemen dasar yang harus diperhatikan dalam perencanaan pengembangan sebuah destinasi pariwisata yang paling tidak mencakup aspek-aspek sebagai berikut.

1. Pengembangan atraksi dan daya tarik wisata. Atraksi merupakan daya Tarik yang akan melahirkan motivasi dan keinginan bagi wisatawan untuk mengunjungi destinasi. Berbagai wujud dari atraksi wisata ini dapat berupa arsitektur bangunan, karya seni, alam, dan pengalaman tertentu ataupun berbagai bentuk event pertunjukan.

2. Pengembangan amenitas dan akomodasi wisata. Amenitas merupakan fasilitas dasar yang disediakan untuk membuat wisatawan merasa nyaman. Amenitas yang disediakan dapat berupa: ultilitas, jalan raya, transportasi, akomodasi, pusat informasi, dan pusat perbelanjaan.

3. Pengembangan aksesbilitas. Yang dimksud dengan aksesbilitas dalam hal ini adalah segenap sarana yang memberikan kemudahan kepada wisatawan untuk mencapai suatu destinasi maupun tujuan wisata yang terkait. 


\section{Posisioning}

Pengembangan image atau citra. Pencitraan sebuah destinasi merupakan bagian dari positioning, yaitu kegiatan untuk membangun citra atau image dibenak wisatawan melalui desain terpadu antara aspek kualitas produk, komunikasi pemasaran, kebijakan harga dan saluran pemasaran yang tepat dan konsisten dengan citra atau image yang ingin dibangun serta ekspresi yang tampak dari sebuah produk.

Pada dasarnya positioning bertujuan untuk membantu wisatawan dalam rangka mengetahui perbedaan yang sebenarnya antara suatu destinasi dengan destinasi pesaingnya. Oleh karena itu, untuk membangun citra pariwisata, maka perlu diketahui bagaimana persepsi wisatawan terhadap destinasi tersebut. Persepsi adalah bagaimana wisatawan membayangkan atau berpendapat mengenai suatu destinasi wisata tertentu. Persepsi tersebut terbentuk sejalan dengan pengalaman wisatawan terhadap suatu destinasi wisata selama berkunjung kedestinasi tersebut.

\section{Peran organisasi}

"Keberadaan suatu orgaisasi yang bergerak dibidang kepariwisataan kenyataannya dapat berada di tingkat masyarakat, swasta atau industry atau bisnis, maupun ditingkat pemerintah dalam rangka untuk mempermudah pengelolaan dan mempercepat pencapaian tujuan pembangunan kepariwisataan itu sendiri. Sedangkan yang dimaksud dengan kelembagaan dalam pengertian ini lebih mengacu pada keseluruhan regulasi yang mengatur tata kelola kepariwisataan" (Bambang, 2013:198)

Berdasarkan UU No.10 Tahun 2009, ruang lingkup organisasi kepariwisataan meliputi :

1. Organisasi Pemerintah
Merupakan unsur pelaksana Pemerintah, dipimpin oleh Menteri yang berada di bawah dan bertanggung jawab kepada presiden dan mempunyai tugas membantu Presiden dan menyelenggarakan sebagian urusan pemerintahan dibidang kepariwisataan. Urusan pemerintahan bidang pariwisata sebagaimana dimaksud pasal 4 ayat (2) huruf c pasal 4 ayat (3) Undang-Undang No 39 Tahun 2008 merupakan urusan pemerintahan dalam rangka penajaman, koordinasi dan sinkronisasi program pemerintah.

2. Organisasi Pemerintah Daerah

Merupakan unsur pelaksana pemerintah daerah dalam rangka penyelenggara desentetralisasi dan otonomi daerah.

3. Organisasi Swasta/Industri

Merupakan orang atau sekelompok pengusaha yang menyediakan barang atau jasa bagi pemenuhan kebutuhan wisatawan dan penyelenggaraan pariwisata, Undang-Undang No 10 Tahun 2009 pasal 1 angka 7 dan angka 8 .

4. Organisasi Masyarakat

Merupakan masyarakat yang mengorganisir dan bertempat tinggal di dalam wilayah destinasi pariwisata dan diprioritaskan untuk mendapatkan manfaat dari penyelenggaraan kegiatan pariwisata di tempat tersebut, Undang-Undang No 10 Tahun 2009 pasal 5 huruf e.

Kelembagaan ini juga sangat berperan penting dalam pembentukan citra destinasi. Penting bagi setiap lembaga atau stake holder mengelola citra sebagai sebuah proses yang sedang berlansung dilakukan dengan cara:

1. Mengidentifikasi, mengukur dan mengendalikan citra produk untuk 
menarik wisatawan dan membangun pangsa pasar yang berbeda.

2. Meneliti citra destinasi berdasarkan segmentasi demografis dan target pasar tertemtu.

3. Posisi manfaat destinasi untuk mendukung citra yang ada atau membuat citra yang baru.

4. Mengomunikasikan manfaat kepada pasar sasaran.

Menurut Aaker dalam Kotler (2006:105) identitas brand terdiri dari serangkaian asosiasi brand unik yang mewakili arti dan janji brand pada customer. Nama brand adalah yang pertama dan mungkin ekspresi terbesar atau wajah dari suatu yang akan dipasarkan. Sebagai basis dalam memulai, orang harus mengerti bahwa citra adalah persepsi dan kebutuhan, tidak sepenuhnya fakta. Elemen brand formal seperti nama, jenis logo dan slogan bersatu membentuk identitas visual suatu brand atau perusahaan. Semuanya harus mencerminkan intisari brand, kepribadian brand, dan kultur perusahaan.

Identitas visual harus dirancang dengan perspektif jangka panjang. Untuk menjamin konsistensi kinerja brand maka akan sangat membantu jika dijelaskan pedoman branding yang menspesifikasikan pemakaian setiap elemen brand. Pedoman semacam ini disebut kode identitas visual.

Kode identitas visual untuk elemen brand harus mengikuti serangkaian kriteria pilihan untuk mengurangi resiko yang memperkuat atau memperlemah brand :

1. Ketersedian: elemen brand harus tersedia dan dapat digunakan di seluruh pasar. Sekarang ini, penting untuk memeriksa ketersediaan domain internet nama brand.

2. Berarti: idealnya elemen brand harus mencakup intisari brand dan mengo- munikasikan sesuatu tentang keadaan bisnis.

3. Mudah diingat: elemen brand yang baik adalah berbeda dan mudah diingat. Nama brand juga harus dibaca dan diucapkan.

4. Dapat dilindungi: adalah penting bahwa elemen brand khususnya nama brand, dapat dilindungi secara hukum disemua Negara tempat brand dipasarkan.

5. Orientasi ke depan: elemen brand yang dipilih dengan baik dapat menempatkan perusahaan dalam pertumbuhan, perubahan dan kesuksesan. Untuk berorientasi ke depan juga berartimemeriksa kemam-puan elemen brand dalam dan memperbarui.

6. Positif: elemen brand yang efektif dapat mengingatkan asosiasi positif dalam pasar yang dilayani.

7. Dapat dialihkan: kemungkinan untuk menggunakan elemen brand dalam memperkenalkan produk baru dipasar yang sama maupun yang berbeda.

\section{METODE PENELITIAN}

Berdasarkan pertanyaan penelitian yang akan di jawab dalam penelitian ini, maka metode penelitian "Analisis City Branding Dalam Pengembangan destinasi Pariwisata Kabupaten Jayapura" adalah perpaduan antara metode deskriptif kuantitatif dan kualitatif. Metode kuantitatif dipakai untuk mengukur secara matematis instrument-instrumen skalatis seperti dalam analisis data secara statistik deskriptif, khususnya data yang berupa angka atau nominal. Sedangkan metode analisis kualitatif digunakan untuk mempertajam analisis kuantitatif. 
Terkait hal tersebut akan diteliti unsur-unsur pembentukan brand positioning Kabupaten Jayapura yang meliputi persepsi pelaku pasar wisata (wisatawan) terhadap potensi pariwisata di Kabupaten Jayapura sehingga nantinya memunculkan City Branding Kabupaten Jayapura.

Selain itu, penulis juga menggunakan tiga alur kegiatan yang terjadi secara bersamaan dalam metode kualitatif, yaitu reduksi data, penyajian data dan penarikan kesimpulan. Dalam reduksi data ini, terdapat proses pemilihan, penyederhanaan, pengabstrakan dan transformasi data kasar yang muncul dari catatan-catatan tertulis yang didapat dari kegiatan di lapangan. Reduksi data digunakan untuk menajamkan dan mengarahkan, serta membuang yang tidak perlu. Sehingga dapat ditarik kesimpulan secara tepat yang kemudian dapat diuji kebenarannya atau diverivikasi.

Dari hasil yang telah diterima, penyajian hasil data akan dilakukan secara informal (dalam bentuk naratif) yaitu mengidentifikasikan potensi yang ada sehingga diperoleh suatu gambaran lengkap dari permasalahan yang ada.

\section{HASIL PENELITIAN DAN PEMBAHASAN}

\section{Data Profil Responden}

Berdasarkan hasil survei responden yang berkunjung ke Kabupaten Jayapura memiliki profil sebagai berikut.

1. Asal wisatawan

Wisatawan terbanyak yang datang berkunjung ke Kabupaten Jayapura berasal dari luar Papua. Dari survei yang dilakukan tercatat bahwa wisatawan yang berasal dari luar Papua sebesar 56,7\% terdiri dari: Ambon, Berau, Jawa, Kalimantan,
NTT dan Sumatra Utara. Namun dari $56,7 \%$ wisatawan yang berasal dari luar Papua ini, sebagian diantaranya memiliki pekerjaan atau bisnis di daerah Jayapura. Sedangkan yang berasal dari papua sebesar 43,3\% dimana wisatawan ini juga sebagian adalah masyarakat Kabupaten Jayapura dan masyarakat yang berasal dari: Kabupaten Sarmi, Biak, Timika, juga Kota Jayapura.

2. Jenis kelamin wisatawan

Wisatawan di Kabupaten Jayapura mayoritas berjenis kelamin laki-laki. Dari survei yang dilakukan, tercatatat bahwa jumlah wisatawan laki-laki sebesar $66,7 \%$ sedangkan wisatawan perempuan sebesar 33,3\%.

3. Usia wisatawan

Wisatawan yang berkunjung ke Kabupaten Jayapura didominasi oleh usia muda. Ini tercatat bahwa kalangan muda yang berusia 16-27 tahun mencapai $76,7 \%$ dibandingkan dengan usia di atas 36 tahun yang hanya mencapai $16 \%$.

4. Tingkat pendidikan wisatawan Wisatawan di Kabupaten Jayapura mayoritas memiliki tingkat pendidikan SMA, diikuti dengan wisatawan dengan tingkat pendidikan Sarajana (S1) dan hanya sebagian kecil saja yang memiliki tingkat pendidikan S2.

5. Pekerjaan wisatawan

Wisatawan di Kabupaten Jayapura kebanyakan berprofesi sebagai wiraswasta. Ini tercatat bahwa wisatawan yang berprofesi sebagai wiraswasta lebih besar persentasenya disbandingkan dengan yang lainnya, dimana hasil wisatawan wiraswasta mencapai 43,3\%.

6. Faktor pendorong wisatawan datang ke Kabupaten Jayapura 
Faktor pendorong wisatawan melakukan kunjungan wisata ke Kabupaten Jayapura dengan tujuan berwisata. Hasil menunjukan bahwa tujuan berwisata sebebsar 53,3\%, walaupun tujuan wisatawan yang berwisata lebih besar dibandingkan dengan wisatawan yang melakukan kunjungan kekerabat, teman dan keluarga, namun tujuan wisatawan yang melakukan kunjungan juga tidak lepas dengan kegiatan berwisata.

7. Jenis transportasi wisatawan

Wisatawan yang berkunjung sebagian besar dengan menggunakan kendaraan mobil. Kendaraan mobil ini bisa berupa kendaraan pribadi atau mobil yang biasa direntalkan. Wisatawan yang datang ke Kabupaten Jayapura tanpa kendaraan pribadi biasanya lebih suka menyewa mobil yang direntalkan dibandingkan dengan menggunakan angkutan umum.

8. Sumber informasi wisatawan

Wisatawan yang mendapatkan informasi dari teman-teman tentang objekobjek wisata di Kabupaten Jayapura mencapai $33,3 \%$ diikuti dengan informasi dari keluarga yang mencapai $30 \%$. Masih jarang wisatawan yang mendapatkan informasi melalui sosial media atau internet tentang wisata Kabupaten Jayapura.

9. Frekuensi kunjungan wisatawan

Wisatawan yang datang berkunjung ke Kabupaten Jayapura sebagian besar merupakan wisatawan dengan kunjungan berulang (repeator). Hal ini tercatat bahwa wisatawan yang melakukan kunjungan ke Kabupaten Jayapura sebanyak lebih dari 3 kali mencapai 33,3\%, persentase ini menunjukkan hasil yang lebih besar dibandingkan dengan wisatawan yang datang berkunjung sebanyak 2 kali $(23,3 \%)$ dan juga 3 kali (20,3\%). Sedangkan untuk wisatawan yang pertamakali berkunjung (first visitor) mencapai $23,3 \%$.

10. Pengeluaran wisatawan selama melakukan perjalanan

Pengeluran wisatawan rata-rata lebih dari 2 juta. Hal ini dikarenakan biaya perjalanan di atau biaya sehari-hari di Kabupaten Jayapura dan sebagian besar Kabupaten lainnya di Papua memang tergolong dengan biaya yang besar atau mahal.

\section{Persepsi wisatawan terhadap Brand atau City Branding}

Berdasarkan hasil survei, persepsi wisatawan terhadap Brand atau City Branding dijelaskan sebagai berikut :

1. Tingkat pengetahuan wisatawan tentang Brand

Sebagian besar wisatawan sudah mengetahui tentang sebuah brand. Hal ini tercatat bahwa wisatawan yang mengetahui sebuah brand mencapai $43 \%$, sedangkan wisatawan yang belum tentu mengetahui brand sebanyak 33\%. Dalam hal ini, wisatawan yang merasa belum tentu mengetahui brand UI, dikarenakan mereka tidak pernah mendengar brand, namun mengenal brand hanya sebagai sebuah simbol atau merk sebuah produk, seperti: Aqua, Coca Cola, Rinso, dan produk-produk lainnya yang sering mereka dengar dan lihat.

2. Sumber informasi brand

Wisatawan mengetahui sebuah brand dari produk dan jasa. Tercatat bahwa wisatawan yang mengetahui brand dari produk dan jasa mencapai 43,3\%. 
3. Brand Destinasi dapat mempengaruhi persepsi atau pandangan wisatawan Wisatawan merasa bahwa brand destinasi atau city branding dapat mempengaruhi persepsi atau pandanngan wisatawan dalam memilih destinasi yang akan dikunjungi. Hal ini tercatat bahwa wisatawan yang berpendapat setuju mencapai $76,7 \%$.

\section{Kualitas Produk Wisata Kabupaten jayapura}

1. Kemudahan aksesbilitas menurut wisatawan

Wisatawan yang merasa tidak setuju dengan kemudahan aksesbilitas di kabupaten Jayapura mencapai 46,7\%. Dapat disimpulkan bahwa sebagian besar wisatawan merasa bahwa akses di Kabupaten Jayapura masih kurang baik. Hal ini dikarenakan banyak jalan-jalan menuju objek wisata dalam masa perbaikandan menjadi penghambat perjalanan menuju objek-objek wisata di Kabupaten Jayapura.

2. Kualitas akomodasi menurut wisatawan

Wisatawan merasa bahwa kualitas akomodasi di Kabupaten Jayapura sudah cukup baik. Hal ini tercatat bahwa hasil wisatawan yang mengatakan sangat setuju dan setuju memiliki besar yang sama yaitu $40 \%$.

3. Kualitas pelayanan menurut wisatawan

Wisatawan yang merasa sangat setuju $46 \%$, sedangkan wisatawan yang mengatakan setuju sebesar 36,7\% dan hanya $20 \%$ wisatawan yang berpendapat tidak setuju. Hasil ini membuktikan bahwa wisatawan merasa puas dengan pelayanan yang diterima, khusunya pelayanan yang ditawarkan oleh masyarakat sekitar objek wisata.

4. Kuantitas fasilitas umum menurut wisatawan

Wisatawan merasa bahwa fasilitas umum yang disediakan di kawasan objek wisata sudah cukup baik. Hal ini tercatat bahwa wisatawan yang mengatakan setuju mencapai $46,7 \%$ diikuti dengan wisatawan yang mengatakan sangat setuju mencapai $33,3 \%$.

5. Kualitas keamanan menurut wisatwan Wisatawan merasa setuju dengan kualitas keamanan objek wisata Kabupaten Jayapura di mana hasil hasil yang mengatakan setuju mencapai $46,7 \%$. Hasil ini dapat disimpulkan bahwa wisatawan merasa keamanan di objek wisata Kabupaten Jayapura sudah cukub baik.

6. Kenyamanan menurut wisatawan Wisatawan merasa setuju terhadap kenyaman yang dirasakan di objek wisata Kabupaten Jayapura dengan persentase mencapai $56,7 \%$ diikuti wisatawan yang merasa sangat setuju dengan persentase mencapai $36,7 \%$. Dapat disimpulkan bahwa sebagian besar wisatawan merasa nyaman saat berpergian atau berkunjung ke objek wisata Kabupaten Jayapura.

7. Keragaman jenis wisata

Wisatawan merasa sangat setuju dengan keragaman wisata yang dimiliki kabupaten Jayapura mencapai 43,3\% dan diikuti dengan wisatawan yang mengatakan setuju sebesar $40 \%$. Dapat disimpulkan bahwa wisatawan merasa tertarik dan merasa puas dengan keragaman jenis wisata yang ada. 
8. Festival

Sebagian besar wisatawan merasa tertarik dengan festival-festival yang diadakan Kabupaten Jayapura. Di mana hasil yang mengatakan sangat setuju dan setuju memiliki besar yang sama yaitu $40 \%$.

9. Sarana transportasi menurut wisatawan

Wisatawan yang merasa sangat setuju dengan ketersedian sarana transportasi menuju objek wisata hanya mencapai $23,3 \%$, sedangkan wisatawan yang merasa tidak setuju mencapai $40 \%$. Dapat disimpulkan bahwa sebagian besar wisatawan masih merasa kurang puas dengan adanya sarana transportasi yang digunakan untuk menuju ke objekobjek wisata di kabupaten Jayapura.

\section{Ekuitas Kabupaten Jayapura}

Dalam ekuitas Kabupaten Jayapura terdapat empat indikator yang digunakan untuk merumuskan ekuitas yang kuat bagi pembentukan brand Kabupaten Jayapura. Empat indikator tersebut diantaranya yaitu brand salience, brand imagery, brand judgments and feelings, dan brand resonance.

1. Brand Salience menurut wisatawan Brand Salience dicari dengan merumuskan top-of-mind dari Kabupaten Jayapura dan apa saja yang paling dilakukan, ingin dilihat atau dibeli (to do, to see, to buy) oleh wisatawan ketika berkunjung ke Kabupaten Jayapura.

2. Brand Imagery Kabupaten Jayapura menurut wisatawan

Berdasarkan hasil survei, menurut wisatawan Danau Sentani merupkan hal yang harus dilihat ketika berkunjung ke Kabupaten Jayapura. Tercatat bahwa wisatawan yang ingin melihat Danau Sentani mencapai 33,3\%.

3. Brand Judgements and feelings menurut wisatawan

Untuk mengetahui bagaimana persepsi responden mengenai brand judgements Kabupaten Jayapura, maka dilakukan penilaian terhadap tiga indikator, yaitu:

a. Kepuasan terhadap produk wisata di Kabupaten Jayapura

b. Keinovatifan di Kabupaten Jayapura

c. Kemenarikan produk wisata di Kabupaten Jayapura.

Penilaian kepuasan terhadap produk wisata di Kabupaten Jayapura dilakukan pada 7 unsur, yaitu: keamanan, kenyamanan, fasilitas umum, kemudahan aksesbilitas, keragaman jesnis wisata, kualitas akomodasi, dan moda transportasi.

4. Brand Resonance Kabupaten Jayapura

Dalam penelitian ini, peneliti mencari sejauh mana loyalitas, keterikatan, rasa berkomunitas dan tingkat subtitusi wisatawan terhadap produk wisata Kabupaten Jayapura.

a. Loyalitas wisatawan terhadap produk wisata Kabupaten Jayapura

Dalam penelitian ini, peneliti mencari sejauh mana loyalitas wisatawan terhadap produk wisata Kabupaten Jayapura. Sebanyak $70 \%$ responden menyatakan akan melakukan kunjungan ulang. Keinginan wisatawan untuk berkunjung lagi menunjukkan bahwa sebenarnya wisatawan memiliki ketertarikan untuk menikmati beragam produk wisata Kabupaten jayapura. Sebanyak 
$66,7 \%$ juga mengatakan bahwa Kabupaten Jayapura layak menjadi destinasi yang wajib dikunjungi dalam hal wisata alam.

b. Analisis Loyalitas wisatawan Wisatawan Kabupaten Jayapura telah memiliki rasa loyalitas pada produk wisata Kabupaten Jayapura. Hal ini terbukti dengan keinginan wisatawan untuk melakukan kunjungan ulang dan dengan pandangan mereka bahwa Kabupaten Jayapura layak menjadi destinasi yang wajib dikunjungi. Selain itu, sebagian besar wisatawan yang ber-kunjung ke Kabupaten Jayapura merupakan wisatawan repeator. Hal ini menunjukkan bahwa mereka tidak bosan untuk melakukan kunjungan ke Kabupaten Jayapura.

5. Posisioning Kabupaten Jayapura

Posisioning Kabupaten jayapura dicari dengan menggunakan dua variabel, yaitu sisi segmentasi pasar wisata dan sisi produk wisata.

a. segmentasi pasar

Berdasarkan data profil wisatawan, maka wisatawan yang datang berkunjung ke Kabupaten Jayapura mayoritas adalah wisatawan usia muda (18-27 tahun) dengan tingkat pendidikan sebagian besar adalah SMA, S1 dan bekerja. Sehingga dapat disimpulkan bahwa wisatawan yang berkunjung ke Kabupaten Jayapura adalah golongan muda.

b. Postingan Kabupaten Jayapura menurut wisatawan

Bila ditinjau dari keunikan dan kualitas produk wisata Kabupaten Jayapura menurut wisatawan bahwa keunikan Kabupaten Jayapura terletak pada keindahan alam dan budaya masyarakat, dimana pelayanan dan fasilitas umum.

\section{Validasi Hasil Analisis}

Temuan-temuan penelitian yang didapati dari hasil analisis perlu dievaluasi dan divalidasi agarhasil analisis nantinya dapat lebih akurat. Hal ini perlu dilakukan atas dasar pertimbangan bahwa ada kemungkinan para responden kurang jujur dalam menjawab pertanyaan pada kuesioner. Teknik wawancara dengan berdasarkan expert judgement, yaitu berdasarkan opini dari bidang terkait. Dalam penelitian ini, narasumber yang diminta pendapatnya adalah Kepala Dinas Kebudayaan dan Pariwisata Kabupaten Jayapura, yaitu Bapak Chris Tokoro. Hasil wawancara sebagai berikut. 
Tabel 1 : Hasil Wawancara

\begin{tabular}{|c|c|}
\hline Pertanyaan & Jawaban \\
\hline $\begin{array}{l}\text { Apa saja potensi daya tarik wisata } \\
\text { Kabupaten jayapura? }\end{array}$ & $\begin{array}{l}\text { Ada tiga jenis wisata yang dikembangkan di Kabupaten } \\
\text { Jayapura, yaitu wisata alam, sejarah dan wisata buatan. } \\
\text { Kabupaten Jayapura saat ini lebih fokus pada wisata } \\
\text { alam dan budaya. Adapun wisata sejarah di kabupaten } \\
\text { Jayapura, namun objek wisata ini kurang berkembang. } \\
\text { perlu adanya perawatan dalam pengem-bangan objek } \\
\text { wisata sejarah (heritage) ini. } \\
\text { Saat ini wisata alam yang sering diperbincangkan di } \\
\text { kabupaten Jayapura adalah danau Emfote (Danau } \\
\text { Love), disebut danau love karena danau tersebut } \\
\text { berbentuk hati. Objek ini sangat indah, dari ketinggian } \\
\text { pinggiran danau love kita juga bisa melihat keindahan } \\
\text { danau sentani. } \\
\text { Di sebelah barat Kabupaten Jayapura sekitar lima } \\
\text { distrik yang berhungan langsung dengan laut pasifik. } \\
\text { Ditempat ini ada beberapa pantai yang indah } \\
\text { diantaranya pantai amai, tablanusu, pantai harlem, } \\
\text { pantaipasai, pantai bukisi dan pantai tarfia demta } \\
\text { dimana pantai-pantai ini menjadi fokus pembenahan } \\
\text { oleh pihak pemerintah daerah Kabupaten Jayapura. } \\
\text { Diakui bahwa sampai saat ini objek-objek wisata ini } \\
\text { belum tertata dengan baik dan harapan pihak } \\
\text { pemerintah dengan promosi yang dilakukan dapat } \\
\text { menarik perhatian para investor untuk mengembang- } \\
\text { kan objek-objek ini. }\end{array}$ \\
\hline $\begin{array}{l}\text { Bagaimana kepuasan pihak pemerintah } \\
\text { terhadap produk-produk wisata yang } \\
\text { dimiliki Kabupaten Jayapura? }\end{array}$ & $\begin{array}{l}\text { Sebagai pemilik, kami sangat senang untuk } \\
\text { mengembangkannya, agar ke depan banyak wisatawan } \\
\text { yang berkunjung ke Kabupaten Jayapura yang } \\
\text { diharapkan dapat meningkatkan PAD dan pendapatan } \\
\text { masyarakat di Kabupaten Jayapura. Sementara ini } \\
\text { pihak pemerintah berada dalam posisi memberikan } \\
\text { penguatan-penguatan kepada semua yang berhubungan } \\
\text { dengan objek-objek wisata di Kabupaten Jayapura agar } \\
\text { kedepan objek-objek wisata dapat lebih bagus dan } \\
\text { menarik. }\end{array}$ \\
\hline $\begin{array}{l}\text { Seperti yang kita ketahui bahwa saat ini } \\
\text { banyak kota-kota besar memiliki brand } \\
\text { destinasi atau city branding, bagaimana } \\
\text { tanggapan pihak pemerintah tentang } \\
\text { sebuah city branding dan apa ada } \\
\text { rencana dari pihak pemerintah dalam } \\
\text { membentuk brand baru bagi Kabupaten } \\
\text { Jayapura? }\end{array}$ & $\begin{array}{l}\text { Benar, Kabupaten Jayapura belum memiliki city } \\
\text { branding. Oleh karena itu akan dilakukan sayembara } \\
\text { dalam pembentukan design city branding. Design } \\
\text { terbaik akan menjadi pemenang. Sayembara ini terbuka } \\
\text { untuk kalangan terbuka, dimana orang yang berasal } \\
\text { dari luar Kabupaten Jayapura bisa terlibat dalam } \\
\text { sayembara ini. }\end{array}$ \\
\hline $\begin{array}{l}\text { Menurut pihak pemerintah, apakah city } \\
\text { branding dapat membantu pengembang- } \\
\text { an sebuah destinasi wisata? }\end{array}$ & $\begin{array}{l}\text { Benar. Sangat penting city branding untuk sebuah } \\
\text { destinasi, diamana branding dapat mengingatkan kita } \\
\text { tentang apa yang dimiliki oleh destinasi tersebut. Jika } \\
\text { Kabupaten memiliki branding, maka orang yang } \\
\text { melihat brand tersbut akan langsung ingat apa saja } \\
\text { yang dimiliki Kabupaten Jayapura termasuk tentang } \\
\text { produk wisata Kabupaten Jayapura. }\end{array}$ \\
\hline
\end{tabular}




\section{Implikasi City Branding}

1. City branding merupakan identitas, symbol, atau image yang melekat pada suatu daerah. Suatu kota biasanya memiliki banyak potensi wisata yang beragam dan hampir tidak mungkin dikemas menjadi satu identitasn tunggal, sehingga harus dipilih beberapa potensi wisata yang benar kuat dan unik dari destinasi tersebut.
2. Kabupaten Jayapura memiliki beragam potensi pariwisata. Namun, seperti yang telah dikemukakan bahwa harus dipilih beberapa potensi wisata yang benar-benar kuat dan unik. Potensi wisata yang telah dipilih itu dapat dijadikan sebagai titik tolak arahan pengembangan pariwisata di Kabupaten Jayapura untuk ke depannya.

\begin{tabular}{|l|l|}
\hline $\begin{array}{l}\text { Positioning } \\
\text { Jayapura }\end{array}$ & Kabupaten \\
\hline Ekuitas & $\begin{array}{l}\text { Kalangan muda, keberagaman daya tarik wisata dan budaya masyarakat } \\
\text { merupakan postingan dari Kabupaten Jayapura. }\end{array}$ \\
& $\begin{array}{l}\text { Yang dapat dijadikan ikon bagi Kabupaten Jayapura adalah Danau } \\
\text { Sentani }\end{array}$ \\
& $\begin{array}{l}\text { Secara umum kinerja produk wisata seperti sarana transportasi dan } \\
\text { aksesbilitas di Kabupaten Jayapura tidak memuaskan. Namun } \\
\text { keragaman wisata alam dan budaya merupakan unsur yang selalu } \\
\text { dipertimbangkan wisatawan untuk datang berkunjung ke Kabupaten }\end{array}$ \\
& $\begin{array}{l}\text { Jayapura. } \\
\text { Loyalitas wisatawan pada Kabupaten Jayapura karena keberagaman } \\
\text { daya tarik wisata yang ada di Kabupaten Jayapura. }\end{array}$ \\
\hline
\end{tabular}

3. Sebelum membaca implikasi unsurunsur brand terhadap kebijakan perencanaan pariwisata destinasi Kabupaten Jayapura, maka perlu dipaparkan terlebih dahulu profil wisatawan yang berkunjung ke Kabupaten Jayapura. Berdasarkan hasil penelitian dan wawancara, maka wisatawan yang berkunjung ke Kabupaten Jaypura adalah: wisatawan dengan uasia muda (produktif) antara 18-30 tahun dengan jenjang pendidikan SMA hingga S1. Daerah asal wisatawan berkisar sekitar daerah Papua dan luar darah Papua. Mayoritas berprofesi sebagai wiraswasta. Frekunsi kunjungan merupakan kunjungan berulang dan hal yang membuat mereka melakukan kunjungan adalah karena wisata alamnya yang memiliki keunikan dan keindahan tersendiri.
Hasil penelitian menunjukkan beberapa kata kunci, seperti: Danau Sentani, Danau Love, dan budaya masyarakat menunjukkan keunikan dan kekuatan Kabupaten Jayapura. Kata kunci-kata kunci tersebut nantinya akan menjadi sebuah arahan (guideline) bagi pengembangan dan perencanaan berdasarkan kekuatan yang dimiliki oleh Kabupaten Jayapura. Selain perencanaan berdasarkan kekuatan yang dimiliki, perlu diupayakan perencanaan untuk memperbaiki kelemahan pariwisata di Kabupaten Jayapura. Sehingga yang menjadi prioritas utama dalam perencanaan dan pengembangan pariwisata Kabupaten Jayapura adalah sebagai berikut :

1. Diversifikasi Atraksi

Pariwisata di Kabupaten Jayapura masih kurang inovatif dan menarik yang membuat atraksi di Kabupaten Jayapura kurang beragam, sehingga perlu adanya diversifikasi atraksi 
terutama atraksi untuk kalangan muda. Atraksi yang dikembang-kan diantaranya adalah kuliner, atraksi night life, pengembangan paket-paket wisata dan pengembangan tema-tema wisata seperti halnya wisata sejarah dan wisata belanja. Dalam pemasarannya, atraksi atraksi tersebut dikemas sedemikian rupa sehingga atraksi tersebut dapat dinikmati atau dilakukan oleh wisatawan dari berbagai kalangan.

2. Transportasi

Berdasarkan temuan penelitian, sistem transportasi di Kabupaten Jayapura terutama yang menghubungkan objek wisata merupakan salah satu produk wisata yang harus dibenahi. Diperlukan adanya suatu transportasi yang menghubungkan antara objek wisata. Angkutan umum atau bus khusus yang hanya berhenti ditempat-tempat objek wisata dapat menjadi alternatif moda transportasi antar objek wisata.

\section{KESIMPULAN DAN SARAN}

Berdasarkan hasil penelitian dan analisis, maka diperoleh kesimpulan sebagai berikut.

1. Persepsi pelaku pasar wisata terhadap citra atau Image destinasi

Pelaku pasar wisata menyatakan bahwa citra atau image untuk Kabupaten Jayapura sebagai kota yang nyaman dan menarik. Kemenarikan Kabupaten Jayapura salah satunya disebabkan oleh keberadaan Danau Sentani yang terbentang luas di Kabupaten Jayapura. Keberagaman wisata alam dan kebudayaan masyarakat yang unik. Keunikan Kabupaten Jayapura inilah yang membedakan Kabupaten Jayapura dengan kompe- titor utamanya, yaitu Kota Jayapura dan Kabupaten Sarmi.

Tidak ada perbedaan persepsi antara wisatawan yang baru berkunjung pertama kali (first time visitor) dan wisatawan yang sudah berkunjung berulang kali (repeator visitor), hal yang membuat Kabupaten menjadi menarik yaitu karena wisata alamnya yang beragam dan budaya masyarakat yang memiliki keunikan tersendiri.

2. Posisioning Kabupaten Jayapura

"Wisata alam yang beragam" dan "budaya masyarakat yang unik" merupakan postingan Kabupaten Jayapura. Dilihat dari segmentasi pasarnya, Kabupaten Jayapura memiliki segementasi pasar yang sangat lokal. Artinya wisatawan yang berkunjung ke Kabupaten Jayapura merupakan wisatawan yang berasal dari Provinsi Papua dan wisatawan nusantara yang sebagian besar juga bekerja di Papua.

3. Unsur-unsur pembentukan brand yang sesuai untuk menyusun city branding Kabupaten Jayapura adalah unik, nyaman, aman Danau Sentani, Danau Love, Wisata Alam, Budaya Masyarakat merupakan unsur-Unsur pembentukan brand yang dapat digunakan untuk menyusun city branding Kabupaten Jayapura. Sedangkan yang dapat dijadikan symbol atau ikon dari Kabupaten Jayapura adalah Danau Sentani. Penyebab danau sentani dianggap sesuai untuk menjadi ikon Kabupaten adalah sebagai berikut.

a. Kepopuleran Danau Sentani di antara para wisatawan.

b. Letak Danau sentani sangat strategis di wilayah Kabupaten Jayapura. 
c. Muatan berbagai sejarah yang terkandung dalam setiap masyarakat Sentani yang tinggal di pulau-pulau kecil Kawasan Danau Sentani.

4. Implikasi unsur-unsur pembentuk city branding terhadap kebijakan perencanaan dan pengembangan destinasi Kabupaten Jayapura. Implikasi unsurunsur pembentuk city branding terhadap kebijakan perencanaan dan pengembangan destinasi adalah sebagai berikut.

a. Revitilisasi bagi wisata budaya atau heritage

meliputi adaptive reuse bangunan sebagai museum atau galeri, pengembangan atraksi, penambahan amenitas, dan perbaikan sarana aksesbilitas.

b. Diversifikasi atraksi

secara umum diversifikasi atraksi ini bertujuan untuk meningkatkan keragamanan atraksi di Kabupaten Jayapura. Pengembangan atraksi ini meliputi kuliner, atraksi, pengembangan di kegiatan festival, pembentukan paket wisata dan pengembangan tematema wisata, sepeti wisata budaya dan wisata sejarah.

c. Pengembangan transportasi Pengembangan transportasi ditujukan, agar akses ke berbagai objek wisata di Kabupaten Jayapura menjadi lebih mudah. Pengembangan transportasi ini berupa pengadaan transportasi, khusus yang menghubungkan antara objek wisata yang satu dengan objek wisata lainnya.

d. Pengembangan fasilitas belanja, dengan menambahkan pusat perbelanjaan souvenir khas daerah.
Berdasarkan kesimpulan diatas, maka saran yang dapat diberikan adalah arahan atau guideline untuk perencanaan destinasi pariwisata Kabupaten Jayapura. Rekomendasi untuk perencanaan dan pengembangan destinasi pariwisata Kabupaten Jayapura sesuai dengan temuan hasil penelitian dibagi menjadi dua bagian yaitu pengembangan produk wisata dan strategi pendukung yang meliputi pembenahan infrastruktur, pelibatan masyarakat dan pemasaran produk. Strategi ini perlu dilakukan karena dapat mendukung keberhasilan dari strategi utama. Secara detail, strategi pengembangan destinasi Kabupaten Jayapura adalah sebagai berikut.

1. Pembentukan Branding pariwisata Kabupaten Jayapura

a. Perumusan city branding yang meliputi perumusan tagline dan symbol atau ikon.

b. Sosialisasi brand terhadap pelaku pasar wisata, baik melalui iklan media cetak maupun elektronik, event-event pariwisata maupun strategi pemasaran lainnya.

2. Pengembangan produk wisata

a. Revitalisasi wisata budaya atau heritage yang meliputi re-use bangunan, penambahan atraksi, dan penambahan fasilitas disetiap objek wisata budaya, seperti: museum dan gallery lainnya.

b. Pemetaan potensi produk wisata pada kawasan objek-objek wisata dan perbaikan infrastruktur

c. Penambahan dan pengembangan atraksi, baik di museum dan festival-festival

d. Pembentukan paket wisata.

e. Penambahan fasilitas belanja souvenir.

f. Perbaikan sarana akses dan transportasi. 
3. Pembenahan infrasturktur

a. Menambahkan penyediaan tong sampah di setiap objek wisata.

b. Perbaikan fasilitas umum yang rusak.

4. Pelibatan komunitas seni

Adanya pembinaan untuk masyarakat dalam membentuk sebuah komunitaskomunitas seni Kabupaten Jayapura yang dapat menimbulkan masyarakat peduli dengan pariwisata.

5. Pemasaran produk wisata Adanya promosi yang baik dalam media iklan, event kebudayaan, brosur, dan website.

\section{DAFTAR PUSTAKA}

Hasan, Ali. 2015. Tourism Marketing. Yogyakarta: CAPS

Brandt, Caline. 2011. "City Branding : A Brand Concept Map Analisis of A Uneversity Town". Vol.7,1(2), 50-63

Braun, Erick. 2012. "Putting City Branding Into Practice" Vol.19,4(2), 257-267

Februandari, Asmari. 2012. Persepsi Pelaku Pariwisata Terhadap UnsurUnsur Pembentuk Citra Destinasi. Tesis. Yogyakarta: Universitas Gadjah Mada

Kontul, George Abraham. 2008. Peran Masyarakat lokal Dalam Hubungannya dengan Citra Sebuah Destinasi Pariwisata. Tesis. Universitas Gadjah Mada

Kotler, Philip. 2006. B2B Brand Manajemen. Jakarta: Bhuana Ilmu Populer
Kusmayadi. 2004. Statistika Pariwisata Deskriptif. Jakarta: Gramedia Pustaka Utama

Nasrulah. 2010. Brand Positioning Sebagai Strategi Promosi Pariwisata Daerah. Tesis. Yogyakarta: Universitas Gadjah Mada

Pariwisata Daerah Jakarta. 2000. Buku Panduan Rencana Pemasaran Pariwisata. Jakarta: Edisi Terbitan di Masa Mendatang

Sugiono. 2011. Metode Penelitian Kuantitatif Kualitatif Dan $R \& D$. Bandung: Alfabeta

Sunaryo, Bambang. 2013. Kebijakan Pembangunan Destinasi Pariwisata. Yogyakarta: Gava Media 